\title{
Dyella-Like Bacterium Isolated from an Insect as a Potential Biocontrol Agent Against Grapevine Yellows
}

\author{
Lilach Iasur-Kruh, Tirtza Zahavi, Roni Barkai, Shiri Freilich, Einat Zchori-Fein, and Vered Naor†
}

First author: Department of Biotechnology Engineering, ORT Braude College of Engineering, Karmiel, Israel; first and fifth authors: Department of Entomology, Agricultural Research Organization, Ramat Yishay, Israel; second author: Extension Service, Ministry of Agriculture, Qiriat Shmona, Israel; third and sixth authors: Shamir Research Institute, Katzrin, Israel; fourth author: Department of Natural Resources, Agricultural Research Organization, Ramat Yishay, Israel; and sixth author: Ohallo College, Katzrin, Israel. Accepted for publication 3 October 2017.

\begin{abstract}
Yellows diseases, caused by phytopathogenic bacteria of the genus Phytoplasma, are a major threat to grapevines worldwide. Because conventional applications against this pathogen are inefficient and disease management is highly challenging, the use of beneficial bacteria has been suggested as a biocontrol solution. A Dyella-like bacterium (DLB), isolated from the Israeli insect vector of grapevine yellows (Hyalesthes obsoletus), was suggested to be an endophyte. To test this hypothesis, the bacterium was introduced by spraying the plant leaves, and it had no apparent phytotoxicity to grapevine. Fluorescent in situ hybridization analysis showed that DLB is
\end{abstract}

ABSTRACT colonizing grapevine phloem. Because phytoplasmas inhabit the same niche, DLB interactions with this phytopathogen were examined. When the isolate was introduced to phytoplasma-infected Chardonnay plantlets, morphological disease symptoms were markedly reduced. The mode of DLB action was then tested using bioinformatics and system biology tools. DLB genome analysis suggested that the ability to reduce phytoplasma symptoms is related to inhibition of the pathogenic bacterium. These results provide the first step in examining the potential of DLB as a biological control agent against phytoplasmas in grapevine and, possibly, other agricultural crops.
Pesticides, fungicides, and bactericides are required in agricultural crops to control insect damage and plant disease. However, these chemicals may pose significant environmental and health risks due to toxicity to humans and wildlife (Lešník 2005). In addition, the development of pest and pathogen resistance reduces these chemicals' efficiency, and leads to more frequent applications and continuously increasing doses. The development of alternative control methods is a high priority for many communities, and microbial biocontrol agents have been suggested as a potential green solution.

Bacteria can benefit plants in several ways: by stimulating growth, accelerating seed germination, increasing tolerance to stress (Bent and Chanway 1998; Bouizgarne 2013; Compant et al. 2005; East 2013; Hardoim et al. 2008; Long et al. 2008), supplying critical nutrients to the host (Bais et al. 2006), and contributing to plant disease resistance (Berg et al. 2005; Chernin et al. 1995; Innerebner et al. 2011). Plant inoculation with beneficial bacteria can reduce the symptoms of diseases caused by fungi, bacteria, or viruses (East 2013; Hardoim et al. 2008). Beneficial bacteria can be applied as biocontrol agents in agriculture, with the advantages of specificity against the pathogen without harming nontarget organisms on the one hand and the ability to evolve, and therefore prevent pathogen resistance in their host, on the other (Hallmann et al. 1997; Ryan et al. 2008; Sanahuja et al. 2011).

Endophytic bacteria inhabit plants' inner tissues for at least part of their life cycle without causing any apparent disease (Stone et al. 2000). These bacteria can contribute to plant resistance by suppressing pathogens, enhancing the plant's immune system (induced systemic resistance [ISR]), or both (Innerebner et al. 2011; Pavlo et al. 2011; Yasuda et al. 2009). Phloem-residing endophytes may be transmitted by sap-sucking insects; therefore, the vector as well

†Corresponding author: V. Naor; E-mail: vered.spielmann@gmail.com

*The $\boldsymbol{e}$-Xtra logo stands for "electronic extra" and indicates that one supplementary table and two supplementary figures are published online.

(c) 2018 The American Phytopathological Society as the host plant can serve as a reservoir of potentially beneficial bacteria. Hence, tripartite plant-bacteria-insect symbioses may serve as sources for beneficial bacteria with possible application in agriculture (Biere and Bennett 2013; Frago et al. 2012). However, to use an endophytic bacterium commercially as a biocontrol agent, it must be efficient, nonphytopathogenic, and cultivable.

Wine grape berries (Vitis vinifera) make up approximately $71 \%$ of global grape production, making them the highest value-added agrifood product in the world (Demiral and Ayan 2011). In 2014, more than 7.8 million tons of grape berries were grown commercially in the United States (Agricultural Marketing Research Center; http://www. agmrc.org/commodities-products/fruits/grapes/) while, in Europe, the production of wine grape berries was 22.6 million hectoliters (Eurostat: http://ec.europa.eu/eurostat/tgm/table.do?tab=table\&plugin= $1 \&$ language $=$ en $\&$ pcode $=\operatorname{tag} 00121)$. Diseases, pests, and viticultural practices greatly affect the consistency of grape production and quality (Bostanian et al. 2012; Emmett et al. 1992). Yellows diseases, caused by phytopathogenic bacteria belonging to the phloem-inhabiting class Mollicutes, constitute a major threat to grapevines worldwide (Marcone 2014; Weintraub et al. 2010). Bois noir, one of the most important grapevine yellows in Europe and the Mediterranean region, is induced by the pathogenic bacterium 'Candidatus Phytoplasma solani' (Lee et al. 1998; Quaglino et al. 2013). This phytoplasma is mainly transmitted to wine grape berries by the polyphagous planthopper Hyalesthes obsoletus (Hemiptera: Cixiidae) from vineyard weeds (Sforza et al. 1998). Both the pathogen (phytoplasma) and insect vector ( $H$. obsoletus) have multiple host plants. In addition, the insect is considered to be an occasional feeder on grapevines (Bressan et al. 2007; Sharon et al. 2015) and, specifically in Israel, the vector propagates and feeds on plants outside the vineyard (Sharon et al. 2005). Therefore, conventional application of pesticides to control the disease's spread in vineyards is inefficient and disease management is very challenging (Bertaccini et al. 2014). Currently, there is no efficient method to control the pathogen.

A Dyella-like bacterium (DLB) was isolated from $H$. obsoletus. This isolate was found in the gut of the insect host, and its prevalence in the planthopper population increased throughout the pest season, 
suggesting that it is an endophyte acquired by feeding (Iasur-Kruh et al. 2017). In addition, these authors showed that DLB inhibits the growth of Spiroplasma melliferum, a cultivable relative of the phytoplasmas, implying that it might inhibit phytoplasmas as well.

The aim of the current study was to test the prospective use of DLB as a biocontrol agent against phytoplasmas in grapevine.

\section{MATERIALS AND METHODS}

Production of DLB culture. To test the ability of DLB to serve as a phytoplasma antagonist, bacterial inoculum was grown by transferring two loops of DLB from crystal violet (CV) plates (sucrose at $66 \mathrm{~g} /$ liter, sorbitol at $10 \mathrm{~g} /$ liter, Luria broth at $2 \mathrm{~g} / \mathrm{liter}$, $0.1 \%$ [wt/vol] $\mathrm{CV}$, and agar at $15 \mathrm{~g} /$ liter) to $250 \mathrm{ml}$ of $\mathrm{CV}$ liquid medium (Luria broth at $6 \mathrm{~g} /$ liter, $\mathrm{K}_{2} \mathrm{HPO}_{4}$ at $2 \mathrm{~g} /$ liter, and $\mathrm{KH}_{2} \mathrm{PO}_{4}$ at $0.5 \mathrm{~g} /$ liter; $\mathrm{pH} 7$ ) in a $500-\mathrm{ml}$ Erlenmeyer flask, and incubating the culture at $28^{\circ} \mathrm{C}$ at $150 \mathrm{rpm}$ for $48 \mathrm{~h}$. Bacteria were collected by centrifugation $(3,500 \times g, 15 \mathrm{~min})$ and washed twice with phosphatebuffered saline (PBS) $\left(\mathrm{NaCl}\right.$ at $8 \mathrm{~g} /$ liter, $\mathrm{KCl}$ at $0.2 \mathrm{~g} / \mathrm{liter}, \mathrm{Na}_{2} \mathrm{HPO}_{4}$ at $1.44 \mathrm{~g} /$ liter, and $\mathrm{KH}_{2} \mathrm{PO}_{4}$ at $0.24 \mathrm{~g} /$ liter; $\mathrm{pH} 7.5$ ). The bacterial concentration was adjusted with PBS to an optical density at $600 \mathrm{~nm}$ of 0.6 (approximately $10^{6} \mathrm{CFU} / \mathrm{ml}$ ) using a spectrophotometer, with $\mathrm{CFU}$ counting on a $\mathrm{CV}$ plate for confirmation. This solution was used in all DLB introduction experiments.

Plant material and growth conditions. All experiments were conducted on grapevine cultivar Chardonnay. All plant types were grown in a growth room under a long-day photoperiod $(16 \mathrm{~h}$ of light) at $24 \pm 2^{\circ} \mathrm{C}$. Several types of plants were used.

Plantlets from tissue culture. Plantlets were propagated in vitro from healthy vines or vines infected with yellows disease and monitored for phytoplasma presence throughout the propagation period, as described by Naor and Zahavi (2011). Two types of ex vitro plantlets from 6- to 8-week-old cultures were used for DLB inoculation experiments: shortly upon removal from the tubes ( 0 to 7 days; young) or 6 weeks after removal from the tubes (old). All plantlets had roots and were grown in potting soil (EN12580; Tuf Merom Golan, Tiberius, Israel) in plastic-covered 0.5 -liter pots to avoid dehydration.

Wood and green stem cuttings. Stem cuttings of one to three internodes from dormant canes were stored at $4{ }^{\circ} \mathrm{C}$ for 3 weeks before transferring to a controlled growth chamber for sprouting for another 3 weeks. Green cuttings were prepared from new sprouts emerging from these canes. Both the wooded and green cuttings were used in the experiments described below. Cuttings from both types were kept in water in the growth room for 7 to 10 days.

DLB introduction into grapevines. To examine the best way to introduce DLB into grapevines, different inoculation methods were

TABLE 1. Dyella-like bacterium detection in grapevine following various inoculation methods ${ }^{\mathrm{z}}$

\begin{tabular}{lc}
\hline Method of inoculation & Percent positive $(n)$ \\
\hline Dip (plantlets and stem cuttings) & $23.1(52) \mathrm{b}$ \\
Leaf smear & $20.0(15) \mathrm{b}$ \\
Leaf spray & $90.9(20) \mathrm{a}$ \\
Injection & $0.0(10) \mathrm{b}$ \\
\hline
\end{tabular}

z Results are combined from all experiments using ex vitro plantlets, wood, and green stem cuttings. Significance between categories is represented by different letters $(\alpha=0.05) ; \chi^{2}=40.15, \mathrm{df}=3, P$ value $\leq 0.0001$, and $n=$ number of samples.

TABLE 2. Dyella-like bacterium survival postinoculation in grapevine ${ }^{\mathrm{z}}$

\begin{tabular}{lc}
\hline Days of survival & Percent positive $(n)$ \\
\hline $4-8$ & $22.5(40) \mathrm{b}$ \\
$11-28$ & $48.1(54) \mathrm{a}$ \\
37 & $0.0(5) \mathrm{b}$ \\
\hline
\end{tabular}

${ }^{\mathrm{z}}$ Results are combined from all experiments using ex vitro plantlets, wood and green stem cuttings. Significance between categories is represented by different letters $(\alpha=0.05)$. G test $=11.83, \mathrm{df}=2, P$ value $=0.004$, and $n=$ number of samples. investigated with the DLB culture described above (Table 1): (i) root dip: young plantlets were submerged in the DLB culture, (ii) stem dip: the basal side of green and woody stems was submerged in the DLB culture, (iii) leaf smear: one leaf from each young plantlet was pricked in several places on the blade with a sterile needle and smeared with DLB culture using a cotton swab, (iv) spray: leaf blades of each old plantlet were sprayed with DLB culture and marked, and (v) stem injection: $20 \mu \mathrm{l}$ of DLB culture was injected into the base of the young plantlet stem using a 30-gauge needle. In all treatments, the new emerging leaves above the inoculation point were sampled 7 to 14 days postinoculation (dpi), and the presence of DLB was determined by polymerase chain reaction (PCR), as described below.

To examine the mobility of DLB in the plant tissue, stem cuttings from dormant canes were submerged in DLB culture for $3 \mathrm{~h}$ under $400 \mathrm{~W}$ illumination at room temperature (RT), then transferred to a growth room as described above. New leaves that emerged from the sprouting bud of each segment were sampled $7 \mathrm{dpi}$. All experiments were conducted using DLB culture or PBS as a negative control. The stem cuttings were divided into long (15 to $20 \mathrm{~cm}$ ) and short ( 5 to $8 \mathrm{~cm}$ ) groups, and the length was considered to be the migration distance of the bacterium. Tissue from newly emerged leaves $(300 \mathrm{mg})$, originating from each examined plant, was taken at different time points postinoculation and tested for presence of DLB by PCR, as described below.

DLB screening in grapevine leaves. Leaf DNA was extracted by the cetyltrimethylammonium bromide method (Lodhi et al. 1994). All DNA samples were kept at $-20^{\circ} \mathrm{C}$ until further use. The presence of DLB in the plants was determined by PCR using specific primers based on the $16 \mathrm{~S}$ ribosomal RNA gene (Supplementary Table S1). PCR $(25 \mu \mathrm{l})$ contained $10 \mu \mathrm{l}$ of Apex Taq DNA Polymerase Master Mix (Genorama, Tartu, Estonia), 5 pmol of each primer, $12.5 \mu \mathrm{l}$ of double-distilled water, and $1 \mu \mathrm{l}$ of DNA template. The PCR consisted of 35 cycles of $94^{\circ} \mathrm{C}$ for $0.5 \mathrm{~min}$, annealing at $63^{\circ} \mathrm{C}$ for $0.5 \mathrm{~min}$ and $72^{\circ} \mathrm{C}$ for $0.5 \mathrm{~min}$, followed by $10 \mathrm{~min}$ at $72^{\circ} \mathrm{C}$.

DLB localization in plants. A fluorescence in situ hybridization (FISH) procedure was performed to verify the presence of DLB and determine its location inside the plantlets, generally following Vorwerk et al. (2008). Leaves for the FISH analysis were sampled from DLB-treated and untreated young ex vitro plantlets 14 dpi. The petiole of the plantlets was manually cut longitudinally and the sections were submerged in $20 \%$ ethanol, $2.5 \%$ acetic acid, and $2.5 \%$ formaldehyde ( $\mathrm{vol} / \mathrm{vol})$. The samples were vacuumed for $3 \mathrm{~h}$, left for an additional $20 \mathrm{~h}$ at RT, and subsequently transferred to $50 \%$ ethanol and stored at $-20^{\circ} \mathrm{C}$. The sections were dehydrated by sequential

TABLE 3. Dyella-like bacterium detection in different types of grapevine plants $^{\mathrm{z}}$

\begin{tabular}{lc}
\hline Plant type or organ & Percent positive $(n)$ \\
\hline Plantlets & $57.5(40) \mathrm{a}$ \\
$\quad$ Old & $30.0(10) \mathrm{ab}$ \\
$\quad$ Young & $10.0(10) \mathrm{b}$ \\
Stem cuttings & $30.8(26) \mathrm{b}$ \\
$\quad$ Green & \\
Wood & \\
\hline z Results are combined from all experiments using root dip and stem dip as methods \\
of inoculation. Significance between categories is represented by different letters \\
$\quad(\alpha=0.05) ; \chi^{2}=10.12, \mathrm{df}=3, P$ value $=0.02$, and $n=$ number of samples.
\end{tabular}

TABLE 4. Migration of Dyella-like bacterium in the stem cuttings from inoculation point ${ }^{\mathrm{Z}}$

\begin{tabular}{lc}
\hline Stem cutting size & Percent positive $(n)$ \\
\hline Short & $33.0(21) \mathrm{a}$ \\
Long & $20.0(5) \mathrm{a}$ \\
\hline
\end{tabular}

z Significance between categories is represented by different letters $(\alpha=0.05)$. Results are from combined experiments. $\mathrm{G}$ test $=0.36$, df $=1, P$ value $=$ 0.55 , and $n=$ number of samples. 
transfers to 80 and $100 \%$ ethanol and then submerged in hybridization buffer (20 mM Tris- $\mathrm{HCl}$ [pH 8.0], $0.9 \mathrm{M} \mathrm{NaCl}, 0.01 \%$ [wt/vol] sodium dodecyl sulfate, and $30 \%$ [vol/vol] formamide) with 10-pmol fluorescent probes for $4 \mathrm{~h}$ at RT. The sections were then washed and visualized under an IX81 Olympus FluoView 500 confocal microscope. Specificity of the detection was confirmed using a noprobe control, and plants that were not exposed to DLB served as a negative control. All treatments were conducted in triplicate.

DLB effect on phytoplasma symptoms. To examine the potential use of DLB as a biocontrol agent against phytoplasmas, young ex vitro grapevine plantlets, either healthy or infected with Stolbur-type phytoplasma, were inoculated by root dip overnight with DLB or PBS as a control (five replicates for each treatment): ex vitro plantlets were thoroughly washed, cut at the root edge, and submerged in either the DLB culture or PBS for $24 \mathrm{~h}$ before planting in a 0.5 -liter pot, as described above. Plant characteristics, including shoot number, shoot length, leaf length, and number of internodes were recorded 5 weeks postinoculation.

Genomic-based analysis of DLB inhibition-related functions. The DLB genome was sequenced and annotated (Lahav et al. 2016), and is currently available from the National Center for Biotechnology Information (accession LFQR00000000). Enzyme Commission (EC) annotations for the DLB genome were retrieved from the Integrated Microbial Genomes Expert Review platform (Markowitz et al. 2014), using the Department of Energy Joint Genome Institute Microbial Genome Annotation Pipeline. The annotation list was scanned to identify potential proteins that may involve secretion of signaling molecules. In addition, EC annotations for the phytoplasma (onion yellows phytoplasma OY-M) genome were retrieved from the Kyoto Encyclopedia of Genes and Genomes database (Kanehisa et al. 2014).
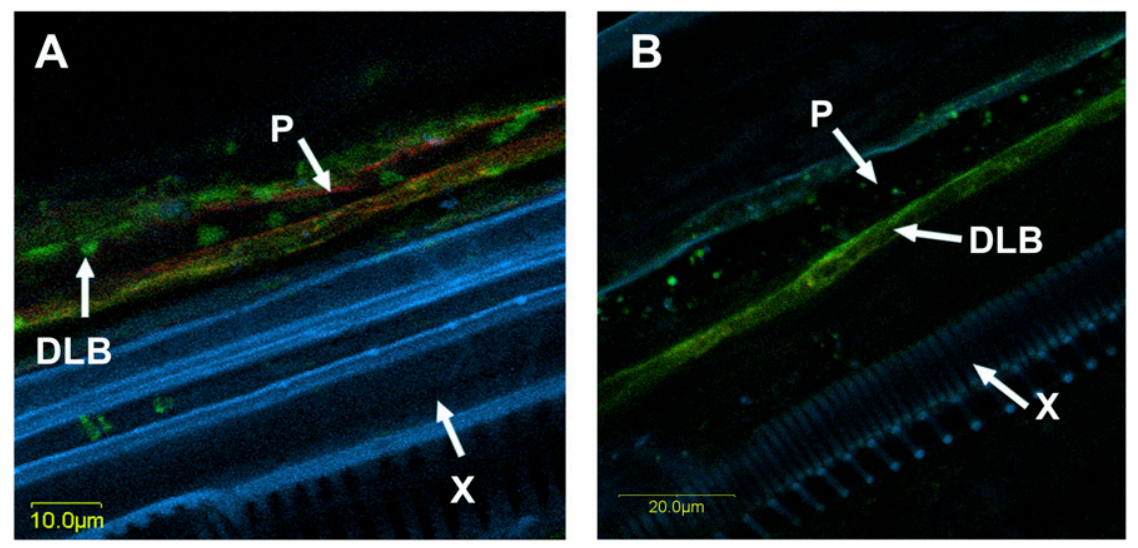

Fig. 1. A Dyella-like bacterium (DLB) is localized in the petiole phloem of grapevine plantlets. Plantlet roots were submerged in a DLB culture overnight and then planted. A, 1 week and $\mathbf{B}, 3$ weeks post inoculation. Fluorescent in situ hybridization analysis was done using a DLB-specific probe and a general bacteria probe (Eub338). Phloem marked as $\mathrm{P}$ and xylem marked as $\mathrm{X}$.
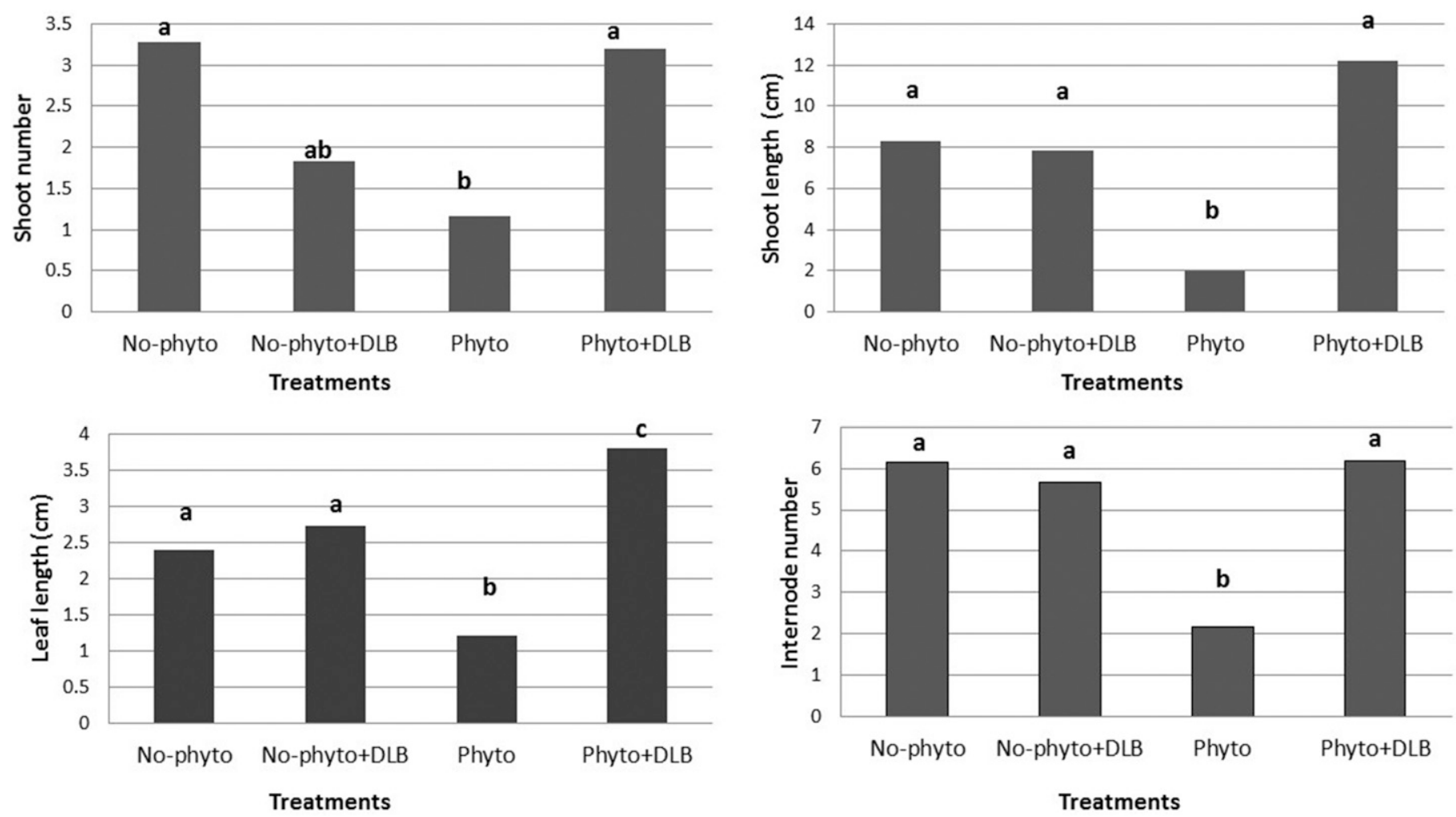

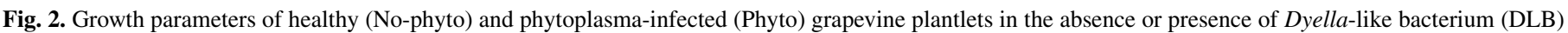

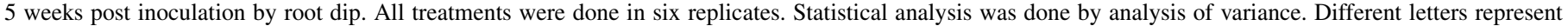
significant differences $(P<0.05)$. 
Based on genomic analysis, the extent of competition over resources between DLB and phytoplasmas was estimated. To this end, we applied the NetCmpt tool that estimates the effective metabolic competition between bacterial pairs (Kreimer at al. 2012). The software takes as input the EC content of bacterial species, translates enzymatic content into species-specific topological networks, applies a topology-based algorithm for the prediction of species-specific metabolic resources (Carr and Borenstein 2012), and simulates growth following the exclusion of common resources.

Statistics. The rate of successful internal colonization by DLB for each category was calculated from the total number of samples for each variable: successful samples/(successful + unsuccessful samples). Statistical significance was calculated using the JMP software. When subgroups were determined prior to experiment, a Pearson $\chi^{2}$ test was used for comparison of subgroups with regards to incidence of success. When subgroups were determined by the experimental results, a $\mathrm{G}$ test was used for comparison of subgroups with regards to incidence of success. In each experiment, the Bonferroni method of correction for multiple comparisons $(\alpha=0.05)$ was used in pairwise comparisons. Means of physiological parameters were analyzed by one-way analysis of variance. Pairwise comparisons were performed by the Tukey test $(\alpha=0.05)$.

\section{RESULTS}

DLB introduction to grapevines. The inoculation method significantly affected DLB internal colonization in the plantlets: leaf spraying seemed to be the most efficient introduction method, with up to $90.9 \%$ of the plants positive for the presence of DLB by PCR a week after treatment, whereas injection into the stem did not result in DLB inhabiting the plants (Table 1). DLB was able to penetrate the grapevine plantlets by all other methods examined. The bacterium survived up to $28 \mathrm{dpi}$ in half of the samples examined (Table 2). No evidence for DLB was detected 6 weeks postinoculation. The highest rate of DLB internal colonization was detected when the bacterium was inoculated into ex vitro old plantlets, whereas the lowest colonization percentage was observed by inoculating DLB into green stem cuttings (Table 3 ). When stem cuttings were submerged in DLB culture, the bacterium could be detected in the leaves of the first growing bud in 20 to $33 \%$ of the samples. The length of the stem cutting did not affect internal colonization rate (Table 4). Furthermore, in several stem-cutting replicates, DLB was also detected in the new leaves of the second internode from the inoculation point (data not shown). PCR produced negative results in all of the DNA extracted from untreated controls.

DLB localization in the plant. Using FISH, DLB could be detected in the phloem of the grapevine leaf's petiole $7 \mathrm{dpi}$ by root dipping in bacterial culture (Fig. 1). None of the untreated control plants showed a fluorescent signal.

DLB effect on phytoplasma symptoms. The effect of DLB on healthy and phytoplasma-infected young grapevine plantlets was evaluated by recording differences in the number of shoots, shoot length, leaf number as well as in the number of internodes. When introduced into healthy grapevine plantlets, DLB did not affect any of the plant parameters tested. However, when DLB was introduced into phytoplasma-infected grapevine plantlets, its presence significantly reduced the symptoms, including marked effects on the number of

TABLE 5. Distribution of enzymatic reactions in metabolic pathways categories (Enzyme Commission [EC]) $)^{\mathrm{y}}$

\begin{tabular}{lcc}
\hline Categories & DLB $^{z}$ & Phytoplasma \\
\hline Amino acid metabolism & 214 & 5 \\
Carbohydrate metabolism & 213 & 32 \\
Metabolism of cofactors and vitamins & 104 & 10 \\
Nucleotide metabolism & 74 & 20 \\
Energy metabolism & 68 & 12 \\
Lipid metabolism & 64 & 7 \\
Xenobiotics biodegradation and metabolism & 44 & 2 \\
Metabolism of other amino acids & 41 & 4 \\
Metabolism of terpenoids and polyketides & 27 & 0 \\
Glycan biosynthesis and metabolism & 27 & 0 \\
Aminoacyl-tRNA biosynthesis & 24 & 19 \\
Biosynthesis of other secondary metabolites & 23 & 0 \\
Total number of enzymatic reactions & 732 & 90
\end{tabular}

y Pathway classifications are according to the Kyoto Encyclopedia of Genes and Genomes (KEGG) scheme. Reactions can be classified to more than a single pathway or not classified. Projection of the EC over the KEGG reference metabolic map is provided in Supplementary Figure S2.

z Dyella-like bacterium.
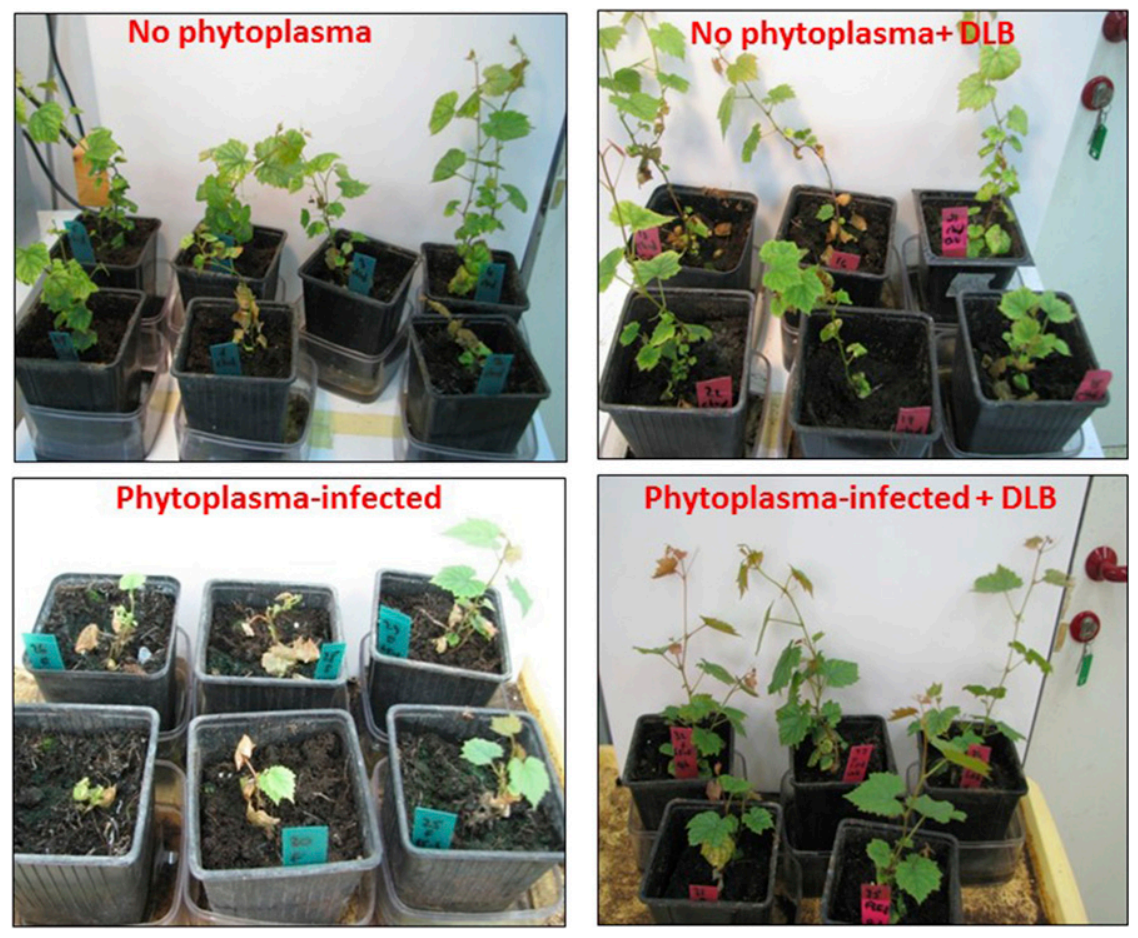

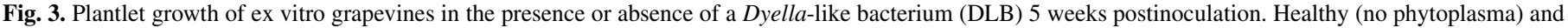
phytoplasma-infected plantlets were root-dipped in DLB culture overnight, planted, and transferred to a growth chamber. 
internodes and shoots, as well as plant and leaf length (Figs. 2 and 3). In the presence of DLB, the growth parameters of infected plants were morphologically similar to those of healthy ones, in contrast to the untreated infected plants.

Genomic-based analysis of DLB inhibition-related functions. Genomic analysis was carried out to compare the metabolic capacities of DLB versus phytoplasma and estimate the overlap in their metabolic inputs (resources). DLB possessed a far more diverse enzymatic set than the phytoplasma (Table 5). The estimated effective metabolic overlap was 0 (according to NetCmpt EMO score), indicating that the growth capacity of these species is not dependent on common metabolites (i.e., no competition was predicted over common nutritional resources between the two bacteria). The ability to produce signaling molecules such as those of the type III secretion system or plant growth regulators (PGR) such as abscisic acid, auxins, cytokinins, ethylene, or gibberellins was not detected in the DLB genome.

\section{DISCUSSION}

In the current study, DLB, a bacterium isolated from an insect vector of phytoplasmas, penetrated grapevines, established itself in the phloem, and reduced the symptoms of the pathogen in infected plantlets. Taken together, the findings suggest DLB's potential as a biocontrol agent against yellows disease.

Several possible disease-suppression mechanisms of beneficial bacteria have been suggested (Eljounaidi et al. 2016). The reduction of phytoplasma symptoms in the presence of DLB might be because (i) DLB competes with phytoplasma for nutrients or suitable colonization niches, (ii) DLB stimulates the plant's ISR, (iii) DLB secretes PGR that enhance plant growth, or (iv) DLB secretes substances that inhibit phytoplasma growth.

The genomic analysis did not support competition for nutritional resources between DLB and the phytoplasma. This might be because, like many other obligatory parasitic bacteria, the phytoplasma's genome has undergone a significant reduction and lost important metabolic genes as a result of its host-dependent life cycles (Oshima et al. 2013). Moreover, we found no evidence of genes involved in ISR or plant growth enhancement in general; however, five secondary metabolites were detected in DLB's genome, including three bacteriocin clusters, one cluster of terpenes, and one cluster of nonribosomal peptide synthetases (Lahav et al. 2016). These results, combined with the fact that the supernatant of the bacterium inhibits spiroplasma growth (Iasur-Kruh et al. 2017), suggest that the most likely mechanism for DLB activity is the production and secretion of one or more antibacterial substances. If such an inhibition mechanism occurs, it could possibly have an effect on the interactions between DLB and phytoplasma within the insect vector. Thus, it would be interesting to know whether the presence of DLB in the insect's gut is affecting both quantity and quality of the phytopathogenic bacteria inhabiting the hemolymph and slivery glands, despite the niche separation. Nevertheless, other mechanisms such as competition over space in the plant cannot be ruled out. In addition, even though DLB belongs to the same family as genus Xanthomonas, no genes coding for the type III secretion system (Boch and Bonas 2010) were detected in the DLB genome, suggesting that it is not a phytopathogenic bacterium (Alfano and Collmer 2004).

Although not frequently investigated, it is well known that endophytes can spread systemically inside the plant and colonize roots, stems, and leaves via penetration through the hair roots, stomata, flowers, and fruit (Hardoim et al. 2015). Endophytic bacterial movement can be either apoplastic, via intercellular spaces (Maheshwari et al. 2013), or facilitated through vascular tubes (Compant et al. 2010; Rosenblueth and Martínez-Romero 2006). Endophytic bacteria are found in different parts of grapevine, including the reproductive organs (Compant et al. 2011). Although most endophytic bacteria inhabit the xylem or the parenchyma of their host plants, several have been found in the phloem as well, including a
Dyella sp., a close relative of DLB that was isolated from the phloem of citrus (Wang et al. 2010). The fact that DLB can move from the root to the shoot through several internodes, combined with its localization in the phloem, suggests this as the path for its movement, as demonstrated for phytoplasma movement by Wei et al. (2004). Furthermore, Chen et al. (1995) examined the effect of six endophytic bacterial strains against Fusarium wilt in cotton and showed that some of them could survive for 28 days in the plant but could not spread more than $0.5 \mathrm{~cm}$ from the inoculation site. Indeed, vertical spread of bacteria through plants may take several weeks (Hardoim et al. 2015). However, in the current study, DLB was detected in the new emerging leaves 1 week postinoculation, suggesting that its mobility inside the stem is adapted to fast colonization, even though it cannot survive in the plant for more than 5 weeks. DLB location in the same tissue as the phytoplasma may hint at possible interactions between the two bacteria.

Because the results indicate that DLB is a candidate biocontrol agent against phytoplasma in grapevine, we further investigated the bacterium's ability to penetrate grapevines by different inoculation methods. Musson et al. (1995) examined the ability of 15 different endophytic bacterial strains belonging to several genera, including Pseudomonas, Bacillus, Brevundimonas, and Enterobacter, to penetrate cotton stems and roots by stab inoculation into the stems, seed coating in bacterial suspensions, soil drench, foliar spray, vacuum infiltration, pruned-root dip, and so on. Based on bacterial reisolation, it was concluded that most of the bacteria studied were effectively established in the plant. However, none of the methods successfully delivered all strains tested, indicating that the optimal method is strain specific (Musson et al. 1995). Similar results were described by Bressan and Borges (2004) and Algam et al. (2005) inoculating endophytic bacteria by different methods into maize and tomato, respectively. Our findings showed that, under laboratory conditions, DLB is best delivered into the plant by leaf spraying. Because grapevine is a perennial crop, this method might be suitable for treatments of mature plants under field conditions. This needs to be further investigated in the vineyard.

\section{ACKNOWLEDGMENTS}

This research was funded by the Chief Scientist of Economy in Israel via the "Kamin" initiative. We thank N. Mozes-Daube, R. Brudoley, R. Kedoshim, and M. Tomer for invaluable technical support; and T. Lahav for helping with the genome analysis.

\section{LITERATURE CITED}

Alfano, J. R., and Collmer, A. 2004. Type III secretion system effector proteins: Double agents in bacterial disease and plant defense. Annu. Rev. Phytopathol. 42:385-414.

Algam, S. A., Xie, G.-L., and Coosemans, J. 2005. Delivery methods for introducing endophytic Bacillus into tomato and their effect on growth promotion and suppression of tomato wilt. Plant Pathol. J. 4:69-74.

Bais, H. P., Weir, T. L., Perry, L. G., Gilroy, S., and Vivanco, J. M. 2006. The role of root exudates in rhizosphere interactions with plants and other organisms. Annu. Rev. Plant Biol. 57:233-266.

Bent, E., and Chanway, C. P. 1998. The growth-promoting effects of a bacterial endophyte on lodgepole pine are partially inhibited by the presence of other rhizobacteria. Can. J. Microbiol. 44:980-988.

Berg, G., Krechel, A., Ditz, M., Sikora, R. A., Ulrich, A., and Hallmann, J. 2005. Endophytic and ectophytic potato-associated bacterial communities differ in structure and antagonistic function against plant pathogenic fungi. FEMS Microbiol. Ecol. 51:215-229.

Bertaccini, A., Duduk, B., Paltrinieri, S., and Contaldo, N. 2014. Phytoplasmas and phytoplasma diseases: A severe threat to agriculture. Am. J. Plant Sci. 5: Article ID 46299.

Biere, A., and Bennett, A. E. 2013. Three-way interactions between plants, microbes and insects. Funct. Ecol. 27:567-573.

Boch, J., and Bonas, U. 2010. Xanthomonas AvrBs3 family-type III effectors: Discovery and function. Annu. Rev. Phytopathol. 48:419-436.

Bostanian, N. J., Vincent, C., and Isaacs, R., eds. 2012. Arthropod Management in Vineyards: Pests, Approaches, and Future Directions. Springer Science \& Business Media, New York. doi:10.1007/978-94-007-4032-7 
Bouizgarne, B. 2013. Bacteria in Agrobiology: Disease Management. SpringerVerlag, Berlin, Heidelberg.

Bressan, A., Turata, R., Maixner, M., Spiazzi, S., Boudon-Padieu, E., and Girolami, V. 2007. Vector activity of Hyalesthes obsoletus living on nettles and transmitting a stolbur phytoplasma to grapevines: A case study. Ann. Appl. Biol. 150:331-339.

Bressan, W., and Borges, M. T. 2004. Delivery methods for introducing endophytic bacteria into maize. BioControl 49:315-322.

Carr, R., and Borenstein, E. 2012. NetSeed: A network-based reverse-ecology tool for calculating the metabolic interface of an organism with its environment. Bioinformatics 28:734-735.

Chen, C., Bauske, E. M., Musson, G., Rodriguezkabana, R., and Kloepper, J. W. 1995. Biological control of Fusarium wilt on cotton by use of endophytic bacteria. Biol. Control 5:83-91.

Chernin, L., Ismailov, Z., Haran, S., and Chet, I. 1995. Chitinolytic Enterobacter agglomerans antagonistic to fungal plant pathogens. Appl. Environ. Microbiol. 61:1720-1726.

Compant, S., Clément, C., and Sessitsch, A. 2010. Plant growth-promoting bacteria in the rhizo- and endosphere of plants: Their role, colonization, mechanisms involved and prospects for utilization. Soil Biol. Biochem. 42: 669-678.

Compant, S., Mitter, B., Colli-Mull, J. G., Gangl, H., and Sessitsch, A. 2011. Endophytes of grapevine flowers, berries, and seeds: Identification of cultivable bacteria, comparison with other plant parts, and visualization of niches of colonization. Microb. Ecol. 62:188-197.

Compant, S., Reiter, B., Sessitsch, A., Nowak, J., Clément, C., and Barka, E. A. 2005. Endophytic colonization of Vitis vinifera L. by plant growthpromoting bacterium Burkholderia sp. strain PsJN. Appl. Environ. Microbiol. 71:1685-1693.

Demiral, İ., and Ayan, E. A. 2011. Pyrolysis of grape bagasse: Effect of pyrolysis conditions on the product yields and characterization of the liquid product. Bioresour. Technol. 102:3946-3951.

East, R. 2013. Soil science comes to life. Nature 501:S18-S19.

Eljounaidi, K., Lee, S. K., and Bae, H. 2016. Bacterial endophytes as potential biocontrol agents of vascular wilt diseases-Review and future prospects. Biol. Control 103:62-68.

Emmett, R. W., Harris, A. R., Taylor, R. H., and McGechan, J. K. 1992. Grape disease and vineyard protection. Pages 242-243 in: Viticulture, Vol. II: Practices. B. G. Coombe and P. R. Dry, eds. Winetitles, Underdale, SA, Australia.

Frago, E., Dicke, M., and Godfray, H. C. J. 2012. Insect symbionts as hidden players in insect-plant interactions. Trends Ecol. Evol. 27:705-711.

Hallmann, J., Quadt-Hallmann, A., Mahaffee, W. F., and Kloepper, J. W. 1997. Bacterial endophytes in agricultural crops. Can. J. Microbiol. 43:895-914.

Hardoim, P. R., van Overbeek, L. S., Berg, G., Pirttilä, A. M., Compant, S., Campisano, A., Döring, M., and Sessitsch, A. 2015. The hidden world within plants: Ecological and evolutionary considerations for defining functioning of microbial endophytes. Microbiol. Mol. Biol. Rev. 79:293-320.

Hardoim, P. R., van Overbeek, L. S., and Elsas, J. D. 2008. Properties of bacterial endophytes and their proposed role in plant growth. Trends Microbiol. 16:463-471.

Iasur-Kruh, L., Naor, V., Zahavi, T., Ballinger, M. J., Sharon, R., Robinson, W. E., Perlman, S. J., and Zchori-Fein, E. 2017. Bacterial associates of Hyalesthes obsoletus (Hemiptera: Cixiidae), the insect vector of bois noir disease, with a focus on cultivable bacteria. Res. Microbiol. 168:94-101.

Innerebner, G., Knief, C., and Vorholt, J. A. 2011. Protection of Arabidopsis thaliana against leaf-pathogenic Pseudomonas syringae by Sphingomonas strains in a controlled model system. Appl. Environ. Microbiol. 77:3202-3210.

Kanehisa, M., Goto, S., Sato, Y., Kawashima, M., Furumichi, M., and Tanabe, M. 2014. Data, information, knowledge and principle: Back to metabolism in KEGG. Nucleic Acids Res.: D199-D205.

Kreimer, A., Doron-Faigenboim, A., Borenstein, E., and Freilich, S. 2012. NetCmpt: A network-based tool for calculating the metabolic competition between bacterial species. Bioinformatics 28:2195-2197.

Lahav, T., Zchori-Fein, E., Naor, V., Freilich, S., and Iasur-Kruh, L. 2016. Draft genome sequence of a Dyella-like bacterium from the planthopper Hyalesthes obsoletus. Genome Announc. 4:e00686-16.

Lee, I. M., Gundersen, D. E., Davis, R. E., and Bartoszyk, I. M. 1998. Revised classification scheme of phytoplasmas based on RFLP analyses of $16 \mathrm{~S}$ rRNA and ribosomal protein gene sequences. Int. J. Syst. Bacteriol. 48: 1153-1169.
Lešník, F. 2005. A medical view of agrochemicals. Folia Vet. 49:4-6.

Lodhi, M. A., Ye, G. N., Weeden, N. F., and Reisch, B. I. 1994. A simple and efficient method for DNA extraction from grapevine cultivars and Vitis species. Plant Mol. Biol. Rep. 12:6-13.

Long, H. H., Schmidt, D. D., and Baldwin, I. T. 2008. Native bacterial endophytes promote host growth in a species-specific manner; phytohormone manipulations do not result in common growth responses. PLoS One 3: e2702.

Maheshwari, D. K., Meenu, S., and Abhinav, A. 2013. Bacteria in Agrobiology: Crop Productivity. Springer Science \& Business Media, New York.

Marcone, C. 2014. Molecular biology and pathogenicity of phytoplasmas. Ann. Appl. Biol. 165:199-221.

Markowitz, V. M., Chen, I.-M., Palaniappan, K., Chu, K., Szeto, E., Pillay, M., Ratner, A., Huang, J., Woyke, T., Huntemann, M., Anderson, I., Billis, K., Varghese, N., Mavromatis, K., Pati, A., Ivanova, N. N., and Kyrpides, N. C. 2014. IMG 4 version of the integrated microbial genomes comparative analysis system. Nucleic Acids Res. 42:D560-D567.

Musson, G., McInroy, J. A., and Kloepper, J. W. 1995. Development of delivery systems for introducing endophytic bacteria into cotton. Biocontrol Sci. Technol. 5:407-416.

Naor, V., and Zahavi, T. 2011. Long maintenance of phytoplasmas in grapevines Chardonnay and Cabernet-Sauvignon in vitro. Phytopathogenic Mollicutes 1:15-20.

Oshima, K., Maejima, K., and Namba, S. 2013. Genomic and evolutionary aspects of phytoplasmas. Front. Microbiol. 4:230.

Pavlo, A., Leonid, O., Iryna, Z., Natalia, K., and Maria, P. A. 2011. Endophytic bacteria enhancing growth and disease resistance of potato (Solanum tuberosum L.). Biol. Control 56:43-49.

Quaglino, F., Zhao, Y., Casati, P., Bulgari, D., Bianco, P. A., Wei, W., and Davis, R. E. 2013. 'Candidatus Phytoplasma solani', a novel taxon associated with stolbur and bois noir related diseases of plants. Int. J. Syst. Evol. Microbiol. 63:2879-2894.

Rosenblueth, M., and Martínez-Romero, E. 2006. Bacterial endophytes and their interactions with hosts. Mol. Plant-Microbe Interact. 19:827-837.

Ryan, R. P., Germaine, K., Franks, A., Ryan, D. J., and Dowling, D. N. 2008. Bacterial endophytes: Recent developments and applications. FEMS Microbiol. Lett. 278:1-9.

Sanahuja, G., Banakar, R., Twyman, R. M., Capell, T., and Christou, P. 2011. Bacillus thuringiensis: A century of research, development and commercial applications. Plant Biotechnol. J. 9:283-300.

Sforza, R., Clair, D., Daire, X., Larrue, J., and Boudon-Padieu, E. 1998. The role of Hyalesthes obsoletus (Hemiptera: Cixiidae) in the occurrence of bois noir of grapevines in France. J. Phytopathol. 146:549-556.

Sharon, R., Soroker, V., Wesley, S. D., Zahavi, T., Harari, A., and Weintraub, P. G. 2005. Vitex agnus-castus is a preferred host plant for Hyalesthes obsoletus. J. Chem. Ecol. 31:1051-1063.

Sharon, R., Tomer, M., Sokolsky, T., Sofer-Arad, C., and Zahavi, T. 2015. Trap plants reduces grapevine yellows disease incidence in commercial vineyards. Phytopathogenic Mollicutes 5:S107-S108.

Stone, J. K., Bacon, C. W., and White, J. F. 2000. An overview of endophytic microbes: Endophytism defined. Pages 29-33 in: Microbial Endophytes. C. W. Bacon and J. F. White, eds. Marcel Dekker, New York.

Vorwerk, S., Sonntag, K., Blaich, R., and Forneck, A. 2008. Application of current in situ hybridization techniques for grape phylloxera (Daktulosphaira vitifoliae, Fitch) and grapevine (Vitis spp. L.). Vitis 47:113-116.

Wang, A. H., Yin, Y. P., Xiong, H. L., Li, Y. F., Li, J., Xian, J. X., and Wang, Z. K. 2010. Endophytic bacterial diversity analysis of Huanglongbing pathogen-infected citrus phloem tissue in Guangxi. Sci. Agric. Sin. 43: 4823-4833.

Wei, W., Kakizawa, S., Suzuki, S., Jung, H. Y., Nishigawa, H., Miyata, S. I., Oshima, K., Ugaki, M., Hibi, T., and Namba, S. 2004. In planta dynamic analysis of onion yellows phytoplasma using localized inoculation by insect transmission. Phytopathology 94:244-250.

Weintraub, P. G., and Wilson, M. R. 2010. Control of phytoplasma diseases and vectors. Pages 233-249 in: Phytoplasmas: Genomes, Plant Hosts and Vectors. P. G. Weintraub and P. Jones, eds. CABI, Wallingford, UK.

Yasuda, M., Isawa, T., Shinozaki, S., Minamisawa, K., and Nakashita, H. 2009. Effects of colonization of a bacterial endophyte, Azospirillum sp. B510, on disease resistance in rice. Biosci. Biotechnol. Biochem. 12: 2595-2599. 